Revue Française de Civilisation Britannique

\title{
Bottom-up versus Top-down Campaigning at the Scottish Independence Referendum 2014
}

La campagne du référendum écossais de 2014: la campagne officielle et la campagne de terrain

\section{Peter Lynch}

\section{OpenEdition \\ Journals}

Electronic version

URL: http://journals.openedition.org/rfcb/405

DOI: $10.4000 /$ rfcb.405

ISSN: 2429-4373

Publisher

CRECIB - Centre de recherche et d'études en civilisation britannique

Electronic reference

Peter Lynch, «Bottom-up versus Top-down Campaigning at the Scottish Independence Referendum 2014 », Revue Française de Civilisation Britannique [Online], XX-2 | 2015, Online since 23 July 2015, connection on 02 May 2019. URL : http://journals.openedition.org/rfcb/405; DOI : 10.4000/rfcb.405

This text was automatically generated on 2 May 2019.

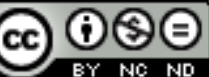

Revue française de civilisation britannique est mis à disposition selon les termes de la licence Creative Commons Attribution - Pas d'Utilisation Commerciale - Pas de Modification 4.0 International. 


\title{
Bottom-up versus Top-down Campaigning at the Scottish Independence Referendum 2014
}

\author{
La campagne du référendum écossais de 2014: la campagne officielle et la \\ campagne de terrain
}

Peter Lynch

1 The proposal to use the referendum device to achieve a mandate for Scottish independence had been the policy of the Scottish National Party since devolution was instituted in 1999. In office after 2007, the party had floated the idea of a two-step referendum on enhanced devolution and independence but its success at the 2011 Scottish election gave it the majority and the mandate required to press for a onequestion referendum on independence. This outcome was not assured in 2011, but came about through the medium of intergovernmental negotiations with the UK government that led to the signing of the Edinburgh Agreement on 15 October 2012. Whilst delivering the independence referendum contained a series of legislative and procedural challenges for supporters of independence, there was also the difficulty of securing a Yes vote at the referendum. The SNP's approach to both devolution and independence up to 2011 had been twofold. The party would seek to use the devolved parliament in Edinburgh as the institution through which to govern effectively and the platform from which to hold an independence referendum. If the SNP were able to show it was successful in government in Edinburgh on policy delivery, this would boost voter confidence in relation to more powers for Scotland and generate support for independence. Despite this strategy, gaining a majority in 2011 and an independence referendum in 2014 were unexpected developments for the SNP.

2 In addition, public opinion was not necessarily easily amenable to supporting independence. The independence option generally trailed behind popular support for devolution as Scotland's preferred constitutional preference. Even though the SNP gained a majority of the seats in 2011 on $45.4 \%$ of the vote, independence was only supported by 
$32 \%$ in the Scottish Social Attitudes Survey of the time, compared to 58\% support for devolution. Support for independence had also slipped as low as $23 \%$ in $2010 .{ }^{1}$ For much of the campaign, the simple Yes/No/undecided opinion poll question found that Yes was behind and frequently substantially by a $20 \%$ margin, with a feeling that Yes would struggle to get as high as $40 \%$ at the referendum. Therefore, independence campaigners were faced with the difficulty of "opinion-reversal" and the "uphill struggle" types of campaigns at the referendum, ${ }^{2}$ meaning Yes had to convert large numbers of people to support independence from a relatively low existing base, and keep them there for the duration of the long campaign. Fighting a long campaign was something they hoped would facilitate a Yes vote, in allowing Yes to generate momentum and build support, whilst exhausting the negative campaigning tactics of its opponents. The referendum campaign itself ran from May 2012 to September 2014, with Yes opting for a long campaign and its opponents, especially Labour, largely choosing to fight a short, focused campaign from May to September $2014 .^{3}$ Yes Scotland's decision to choose a long campaign was effective in part as Yes achieved $45 \%$ and some of the structural realities of the political and media environment generated some interesting strategies and organisational responses from the Yes campaign with its mixture of top-down and bottom-up campaign initiatives, as it finally grew into a mass social movement. It knew it was too small in 2012 and therefore adopted a diverse approach to growing its support from then until 18 September 2014. And, significantly, this growth continued after the referendum itself as arguably, a mass movement for independence was created for the first time in Scotland.

3 Two key points are worth making about the Yes campaign from the outset. First, the campaign itself was a hybrid campaign, both by design and by default. It was partly the result of an electoral campaign machine, recognisable to election-watchers around the world, with political communications professionals and strategies, political marketing through the media and online, an electoral database, centralised fundraising and the production of campaign materials. However, Yes was also a loose social movement that implemented some of the central Yes Scotland strategies and functions, but was also much more free-flowing, numerous and autonomous with activities similar to social movement repertoires and to recent anti-austerity movements. ${ }^{4}$ Second, the Yes campaign created a political movement where none existed before. There were Yes campaigns at the devolution referendums in 1979 and 1997, plus a range of Home Rule pressure groups and organisations since $1918,{ }^{5}$ but this was the first time that the proindependence forces actually became a broad social movement and built a grassroots in a comprehensive way. The 2014 referendum saw prominent roles for the SNP, Scottish Green Party and Scottish Socialist Party, but it also saw the involvement of tens of thousands of non-party indviduals and the creation of a large number of autonomous organisations to promote a Yes vote like National Collective, Radical Independence and Women for Independence. Therefore, though there was a clear No vote in 2014, one unintended consequence of the campaign was the creation of a mass movement in favour of independence for the first time. This movement involved people politicised during the campaign who then became mobilised into political activism and, significantly, the mobilisation continued after the referendum itself. Yes lost on 18 September but lived on through the dramatic growth in membership and popularity of the Yes parties plus the continuation of many of the Yes local groups and organisations. 
The Yes campaign faced considerable negative structural realities at the outset of the campaign that shaped its strategy and campaigning. First, the Yes parties were relatively small - meaning a large SNP with 25,642 members and a place in government, but two small parties in the shape of the Greens and SSP with modest resources and campaign abilities. This was not seen to be large enough to win, therefore an alternative model was required. Second, there was a feeling that the party approach would be ineffective as a campaign strategy to make Yes less SNP-like, not least that the campaign needed to reach out to voters outside the parties and also to Labour voters who generally opposed the SNP: part of the tribalism of modern Scottish politics. Third, the media, in terms of the printed press, were likely to be anti-independence throughout the campaign. Yes therefore had to find a way to connect with voters that recognised these structural realities. This situation fed the Yes social media campaign, which was extensive, but also the support for grassroots initiatives that sought direct contact with voters through street campaigning and canvassing. Yes sought to bypass the media to go directly to voters through its local campaigners and ordinary supporters. At the same time, it sought to build its own crowd-funded media of bloggers, news websites and networks on Facebook and twitter. ${ }^{6}$

\section{Top-Down and Bottom-Up Campaigning - A Thousand Flowers Bloom}

5 When Chairman Mao raised the prospect of China allowing a "hundred flowers to bloom" in 1956, he obviously didn't foresee his phrase being subject to inflation and adopted by Yes campaigners in Scotland in 2014. ${ }^{7}$ The adoption of the "thousand flowers" theme was a consequence of the structural weakness and political environment for Yes, a sign of its internal diversity and also of obvious contrasts that Scottish campaigners made with Catalonia. Scotland's quiet nationalism and mobilisation compared badly with the noisier, public demonstrations by the Catalans with their mass rallies and capacity to mobilise huge numbers of supporters well beyond the political parties. These activities provided food for thought for Yes campaigners about how to reach beyond the parties to connect with more voters, knowing that they faced an unsympathetic media. And, in a sense, this explicitly meant how campaigners could reach voters who were partisans of the SNP's opponents - principally Labour - or not partisans at all, but part of an electorate that had grown distrustful of political parties and institutions in recent years: something that was a challenge for a movement seeking serious institutional change. Yes therefore sought to campaign with and without politicians and parties, to focus on communities, families and one-to-one campaigning and conversion efforts.

6 The challenge with characterising the Yes campaign simply is that it contained so much in terms of orthodox and unorthodox political activism and elements that appeared unfamiliar to political activism in traditional UK party politics. Within the broad Yes movement you could find traditional elements of political campaigning like canvassing, leafleting, public meetings, etc., as Yes groups engaged with the public in some very traditional ways. There was an old school element to Yes campaigning as its grassroots approach breathed new life into street work as opposed to the types of electoralprofessional communications that came to dominate contemporary UK campaigning as it was transformed into people-less political marketing. At the same time, Yes made extensive use of the media and particularly social media. Yes Scotland and organisations 
such as National Collective ran daily social media campaigns and some very effective campaigns across the referendum that connected hundreds of thousands of voters. Finally, there was a strong DIY element to Yes campaigning, with local groups organising events, social media campaigning and literature. And that's before considering music, festivals, new media journalism, cartoons, performance poetry, art, football fans' groups, drop-in cafes, graphic design, etc., and the wide expanse of Yes activities outside of electioneering that sought to build support across the long campaign from different political directions - from the radical left, the Greens, cultural organisations or the women's movement. Events by local Yes groups often featured non-party figures like authors and playwrights Alan Bissett and David Greig, poet Liz Lochhead, author Janice Galloway, traditional musicians like Karine Polwart and Dougie McLean amongst many others as Yes took on a cultural festival feel with story, poetry and song. National Collective's Yestival summer tour on 2014 contained a huge variety of cultural figures, old and new. ${ }^{8}$

7 One prominent theme in research into political parties in recent decades has been the rise of the electoral-professional party, ${ }^{9}$ as parties became centralised, political communications machines that connected with voters through the mass media and direct mailing operations. Political campaigning in this sense became a type of marketing, practiced by professionals using focus groups and surveys to identify key voters in swing seats, with campaigns that focused on party positioning, key messages, etc., so that elections became a form of retail politics. ${ }^{10}$ Closely related to these developments was the atrophying of local party organisation and party membership. ${ }^{11}$ Quite simply, elections became dominated by media campaigning, not by grassroots campaigning, unless you happened to live in a key marginal constituency. This situation was very evident in the UK, where political parties were seen to be in serial decline in recent years, albeit that this reality did not affect all of them: both the SNP and UKIP were increasing their membership in recent years. And, during the campaign itself, Yes grew at the grassroots as it added large numbers of supporters and activists to its ranks. Events like the Independence march and rally in 2013, the turning of the New Year in 2014 and George Osborne's decision to rule out Scotland sharing the pound after independence in early 2014 produced more Yes activity on the ground. The closing weeks of the long campaign also saw many people becoming active. Significantly, many of these people became politically active for the first time and came from outside the ranks of party memberships. And they came in large numbers so that Yes had tens of thousands of activists involved on the ground on a weekly basis, learning political campaigning techniques and becoming familiar with the political terrain in their communities.

of course, whilst the notion of an electoral-professional organisation gives some sense of the hollowing out of political parties beneath the central organisation, it also infers that there is a right way to do campaigning and a wrong way, and that some political activities are amateurish. How did the professional-amateur divide work at the referendum campaign? Whilst Yes had communications and marketing professionals, it seemed to lack electoral organisation staff aside from its electoral database team. Yet, the grassroots and range of autonomous organisations in the broader Yes campaign were also a mix of professional and amateur activists. The movement contained large numbers of activists who were skilled in campaign organisation, use of social media, printing, graphic design, etc., so that some of the grassroots activities defied description as amateur. Widespread availability of digital media facilitated the creation of a campaign army of bloggers, 
Facebookers, tweeters and photographers. Campaigners also had time to learn new skills over the long campaign. Often, this was a case of activists applying existing skills and networks to the Yes campaign. The National Collective and its associated organisations were a strong example of this - as it hosted events, including a national tour (Yestival), ran theatre and cabaret at the Edinburgh Festival, published books ${ }^{12}$ and magazines, produced photo collections, cartoon books, ${ }^{13}$ acted as a forum for writers, journalists and campaigns to publish their views and also participated in street campaigning. Its activities were promoted extensively through social media by the organisation and its supporters with a considerable reach into the hundreds of thousands, meaning greater than much of the traditional media in Scotland. ${ }^{14}$

When it comes to a central activity like campaign fundraising, the professional-amateur dichotomy comes under pressure. Yes Scotland raised the largest sum of money of any Yes organisation, yet it was a weak fundraiser compared to Better Together by some distance. The fact that Yes was not such a successful fundraising organisation undermined its campaigning efforts at the electoral level in particular when it came to direct mail and voter targeting. One internal campaign document had outlined the goal of raising 24 million and winning $65 \%$ of the vote. Instead, it only raised around 4.8 million for the campaign. ${ }^{15}$ However, other components of the Yes campaign were effective fundraisers, albeit in smaller amounts. A large amount of Yes activity was crowd-funded through the indiegogo website mechanism. This fundraising platform charged a percentage fee for the fund, but allowed funding to be raised centrally online, before transfer to the campaign group. Such crowdfunding was promoted through social media by Yes supporters and groups far and wide. Yes groups raised small amounts for specific purposes like a campaign shop or mobile advertising trailer but also for campaigns, materials and broader activities from festivals to websites to films. Local groups crowdfunded but so did national organisations like National Collective, Radical Scotland and Women for Independence.

10 The hybrid Yes campaign was also typified by its mixture of traditional and nontraditional campaigning. Sure enough, it excelled at social media campaigning, with multi-channel campaigning through Facebook, Google plus, twitter, Kiltr (a Scottish social networking forum) instagram, etc. It also made extensive use of YouTube and vimeo for campaign videos by the official Yes campaign but also by a variety of Yes groups and individuals. At times, it seemed everyone saw a future in online film. Events were often filmed for upload later and events large and small were streamed live. ${ }^{16}$ National Collective's Yestival became available online but then so did small public meetings held up and down Scotland. Yes funded a large number of infographic production for Facebook and other channels, which fed into graphic design, T-shirts, posters, mugs, badges, etc. As explained above, campaign funding was also raised through social media.

11 However, allied to the technology was some very traditional campaigning, aimed directly at convincing voters. The public meeting/debate made something of a comeback. Sometimes these were organised affairs run through Eventbrite. More often, they were just public meetings held in church halls, cafes and village halls. Hundreds were held, with tens of thousands attending. The idea of the public meeting was to attract undecideds to discuss the issues. However, many of the public who attended were probably already supporters of Yes or No at the referendum. Yet, such public meetings helped to galvanise Yes in particular as the meetings generated new activists and 
supporters. So new converts to vote Yes may have been small, but the meetings were a core part of building a mass movement. Street stalls also ran regularly to provide information about the case for Yes, either in set weekly locations or in geographical rotation depending on the local Yes group and geographic nature of the community. These stalls had multiple functions: they were key to obtaining signatories for the Yes declaration, generating support, building a network, distributing campaign materials and for connecting with the public generally. Face to face contact was central to the Yes campaign through stalls but also through door to door canvassing. Armed with a copy of the electoral register, campaigners would knock the doors to ask people where they placed themselves onto a 1-10 scale (1 was totally opposed to independence, 10 was totally in favour). This data was then inputted to Yesmo, the campaign database to sift out supporters and undecideds, who were then to be subject to further campaigning. The use of the database also had a second function, that of voter registration. The database was one of the keys to determining whether members of a household could vote at the referendum and, for demographic reasons, many of the unregistered were likely to be Yes voters. The database was key to ensuring Yes was able to register as many voters as possible though, in fact, campaigners visited colleges, job centres and bingo halls to find unregistered voters, which didn't rely on the electoral register or Yesmo database at all.

\section{Yes at the Centre}

12 The Yes campaign featured at least one defined centre in Yes Scotland. This umbrella body was launched on 26 May 2012 as the official Yes organisation. It had an office in Glasgow, a cross-party advisory board of politicians and supporters, permanent staff, campaigning functions in terms of media, special media, organisation and electioneering. It was created with a team of directors in 2012, but most of these were no longer in post by 2014 as the organisation faced internal problems which affected its direction and finances. These developments did not inspire confidence at the grassroots. The loss of senior staff plus the manner in which the organisation had received large donations from a couple of SNP supporters who had won the Euromillions lottery probably deterred supporters from donating to the Yes campaign centrally, with consequent negative effects in its campaigning.

Yes Scotland had a number of strategies to develop support for independence. First was the Yes declaration itself. The declaration was a symbolic device that supporters would sign to demonstrate they supported independence. Supporters could sign online or in person at Yes stalls and events. The intention was for Yes to recruit one million signatories. In the absence of official membership processes, this was effectively how supporters joined Yes and became involved. The fact that Yes were able to announce that they had achieved 1,001,186 signatures in 2014 was certainly a boost to the organisation (announced on 22 August 2014). The collection of signatories was not a simple process when completed manually through stalls and events. Individual signatories were often unclear in terms of hand-writing and addresses and had to be checked with the electoral register; moreover, there were signatories who could not be matched with the electoral register, so getting to the million given that reality was impressive. However, the million had practical as well as symbolic aspects. The declarations asked for names, addresses, phone numbers and emails where possible, so that Yes centrally and locally were able to contact supporters to seek campaign support, donations and circulate key messages. As 
individual Yes supporters were to be recruited as campaigners with their friends and families, the collection of a huge email database was useful for circulating Yes briefings on key issues like currency, the NHS, the job creation powers of independence, etc. It was also used to prompt people to join local campaign events and share infographics on social media like Facebook.

Yes Scotland also had a role in developing sectoral groups in support of Yes, which were intended to take on a life of their own once launched. Staff at Yes Scotland helped organise a variety of groups such as Sport for Yes, Academics for Yes, Farming4Yes, Generation Yes [Yes Youth and Students], Yes NHS, Teachers for Yes, Trade Unionists for Yes, etc. The launch of these groups was aided by Yes, especially the organisation and press launches, but then were left to their own devices to some extent, with some becoming formally independent of Yes and registering as separate organisations. What the groups did was allow Yes to extend its social and organisational reach into civic society in key policy and professional areas so that the independence message was seen to be relevant across a whole range of areas. Second, they generated Yes organisation within key sectors, so that medical staff, lawyers, care workers, architects, teachers, etc., all became advocates for independence in their own professions and used their expertise to make the case for a Yes vote.

The third major role practiced by Yes centrally was in general campaigning through the media and social media. Alongside the Scottish Government and the SNP, Yes was a key producer of political discourse, policy and ideas at the referendum. These were promoted through the traditional media but also through extensive use of social media in terms of events, announcements, photo opportunities, the role of Yes spokespersons on TV and radio, the production of Yes videos on YouTube for distribution on social media as well as a vast number of infographics for social media distribution and sharing. Yes also produced campaign materials in the shape of leaflets, booklets, posters and badges, with lots of material sold through the online Yes shop. The central organisation was also responsible for booking newspaper and billboard advertising across Scotland. That's not to say that local Yes groups did not do these things: they did. Yes locally was extremely creative in terms of producing campaign materials at all levels of campaigning, aided by social media and new technology, to the extent that the referendum generated a cottage industry of Yes campaign production (some of which continued after the event).

The final function of Yes Scotland as a central organisation was its role in creating and operating the Yes database of supporters, Yesmo. This involved establishing and running a database of all registered voters in Scotland from the autumn of 2013 to referendum day itself. The database logged supporters, opponents and undecideds in relation to independence and provided a platform for some targeted campaigning during the referendum locally. It was also used for voter registration, encouraging turnout by postal voters and then organising the 'Get out the Vote' organisation on referendum day itself. It allowed local campaigners to target undecideds and allowed the central campaigners to monitor levels of support for Yes/No throughout the campaign. As a targeting device it had limited potential due to the weak capacity of Yes Scotland to exploit its own data and target key voting groups centrally. Lack of electoral expertise and finance were issues here, with Yes targeting of specific social groups coming very late in the campaign. 


\section{Yes at the Grassroots}

17 The grassroots level of Yes had numerous dimensions and no single model. Indeed, it was characterised by its organisational diversity. Yes Scotland sought to generate Yes groups across Scotland through the Yes Communities section of its office in Glasgow. Besides the sectoral groups part of Yes, the local communities campaign was the most effective. The organisation toured Scotland in the summer/autumn of 2012 to try to establish local Yes groups around Scotland's 32 local authority areas. In time, these groups mushroomed in number and in geographical shape and there was considerable diversity amongst the 300 or so groups established on the ground. ${ }^{17}$ Some local groups followed constituency organisational models - meaning they followed the 73 Scottish parliament and/or 59 Westminster constituencies. Other groups followed local community models based on towns or villages. Some began as local authority groups and then decentralised into local groups. Some overall coordination by cross-boundary groups was also required. Yes Edinburgh for example was actually a shell organisation, which contained many local and constituency-based groups beneath it. But it was able to act to coordinate monthly mass canvassing across the city in 2014, which had the effect of delivering 150-250 campaigners to a specific area of Edinburgh for a day's intensive campaigning (the Yes Super Saturdays). Other local Yes groups and organisations like Radical Independence adopted similar mass canvassing activities to target specific communities to register voters and bring the case for independence onto people's doorsteps.

The local groups were mostly self-starting and comprised of a range of people not just SNP activists, something that must be stressed. In some areas, the local SNP was the backbone of Yes, due to numbers of local campaigners, political experience and campaign knowledge on the ground. However, Yes locally was notable for its diversity on the ground - meaning the involvement of Greens, Socialists and many independents, including large numbers of activists who were first-time campaigners and often outnumbered the SNP contingent in the local campaign. The local Yes groups grew through mechanisms like the nationbuilder computer programme on the Yes Scotland website where they organised and advertised local events, through Yes email "blasts" of events to supporters and to the local emailing lists and Facebook pages of the Yes groups. Local campaigning and events also generated new supporters and campaigners regularly throughout the campaign as Yes grew at the local level in a very organic way. Local Yes activity tended to generate more engagement from supporters so that activism tended to snowball during the campaign.

The second main type of grassroots initiatives came with the creation of a series of autonomous Yes-supporting organisations during the campaign, from diverse sources. These organisations became independently registered with the Electoral Commission, with their own memberships, finances and internal organisational arrangements. They were not established by Yes Scotland. For example, the Radical Independence Campaign was launched at a conference in Glasgow in November 2012. ${ }^{18}$ It began as a conference of ideas and discussions and then morphed into a loose central organisation with local groups that became involved in local campaigning. It comprised a range of Greens, Socialists and non-party activists from social movements and organisations across Scotland. It sought to create its own grassroots and local branches grew during the referendum campaign and stood at 21 in November 2014, especially in the major cities. ${ }^{19}$ 
The organisation campaigned locally in a number of areas, especially in housing schemes. It organised a series of mass canvasses of working class voters in Glasgow and Edinburgh amongst other areas, intended to ensure voters were registered but also to talk to voters about the case for independence. These latter aspects were key as the best demographic support for Yes was amongst working class voters and, in some areas, these voters had disappeared from the electoral rolls or simply stopped voting. Ideologically, Radical Independence also proposed a more radical form of independence that sought a greener, more redistributive Scotland that would be a republic with its own currency. ${ }^{20}$ The organisation saw its third conference in Glasgow attract 3,000 delegates spread across a range of venues on 22 November 2014, on the same day as the new SNP leader Nicola Sturgeon was speaking to 12,000 party members at the nearby Hydro arena.

Second, and quite different to Radical Independence, was Business for Scotland, a proindependence business networking body that was created in March 2013 by six business owners from the SME sector in Scotland. Through a series of business networking events, fundraising, media and social media activities, the organisation grew to 3000 members. Business for Scotland presented economic analyses and materials on the case for Yes, challenging the arguments of the media and anti-independence businesses in Scotland on currency, oil and gas, tourism, taxation, job creation, etc. The organisation produced its own ambassador programme to increase its speakers and presence across Scotland to take the case for independence to the SME community in particular. ${ }^{21}$

Third, was Women for Independence, which was formed on 29 March 2012 and officially launched in September 2012 as a broad women's organisation for independence which also campaigned on a wide range of issues around women's representation in Scottish political life and the workforce..$^{22}$ The organisation grew through social media and blogging and was launched with only 100 members. Its campaign efforts and social media presence on International Women's Day on 8 March 2014 gave the organisation a level of prominence in the referendum campaign, not least as it contained a number of prominent voices at a time when the Yes vote amongst women voters was seen to lag significantly behind men. Figures from Women for Independence featured in the media, and organised their own events and campaigning activities and networks. The group continued after the referendum, having morphed into an organisation that hosted a conference with 1,000 participants and had over 50 local groups active in political campaigning. ${ }^{23}$ Local groups created shops, campaign group and began to get social and political issues on the agenda for women, not least quotas and 50/50 representation as well as the issue of a new women's prison ${ }^{24}$. Significantly, each of these prominent groups decided to continue in existence after the referendum, demonstrating the potential longevity and resilience of the Yes movement.

\section{Conclusion}

Though Yes lost the referendum, the long campaign had significant legacy effects, which reflected the fact that a sizeable national movement had been formed for the first time. The hybrid campaign generated a range of new organisations that continued post-"indyref", with diverse activities and strategies that used the online world to build their networks and support bases. These organisations developed nationally and locally through a variety of traditional and modern methods of campaigning and, most significantly, they actually grew and solidified rather than collapsed after 18 September. 
Further constitutional reform is very much on the agenda in Scotland and in the rest of the UK as the referendum helped spark constitutional debate and demands. Governments, parties and pressure groups became actively involved in post-referendum discussions on further devolution. In addition, the politicisation and mobilisation effects experienced during the referendum campaign actually continued afterwards. In spite of the result, Yes activism continued after the referendum in a variety of ways. In the party sphere, the SNP saw its membership boom from 25,642 on 18 September to 93,000 by early 2015 (the SNP computer system and office couldn't cope with the demand). The Scottish Greens surged from 1,200 members before the referendum to 7,057 on 12 October 2014 and struggled to send out membership packs to deal with the Green surge. The Scottish Socialist Party had to find money to send out membership packs to 2,500 new members who joined its ranks in the five days following the referendum. Organisations like Radical Independence and Women for Independence continued after the referendum with conference attendances larger than during the campaign itself - the Radical Independence conference had to move venue to a concert hall to accommodate 3,000 delegates. Women for Independence also began to establish local groups and the semblance of a branch network, as post-referendum activity continued to see localisation strategies and network-building to create a larger organisation than existed during the referendum campaign itself. Similarly, Yes groups continued to function, with strategic discussions about approach to future activities, from possible Yes Alliance candidates for the 2015 British general election to the future of the Yes movement at all levels, despite the demise of Yes Scotland as a central organisation.

\section{BIBLIOGRAPHY}

ADAMSON, Kevin \& LYNCH, Peter (eds.). Scottish Political Parties and the 2014 Independence Referendum. Cardiff: Welsh Academic Press, 2014.

BRAND, Jack. The National Movement in Scotland. London: Routledge and Kegan Paul, 1978.

CASKIE, Kathleen. “Women Seeking a State of Independence”, Scottish Left Review, issue 84, 2014.

CASTELLS, Manuel. Networks of Outrage and Hope: Social Movements in the Internet Age. London: Polity, 2012.

CURTICE, John \& ORMSTON, Rachel. Scottish Independence: The State of the Union: Public Opinion and the Scottish Question, British Social Attitudes, 29, 2012.

FOLEY, James \& RAMAND, Pete. Yes: The Radical Case for Scottish Independence. London: Pluto, 2014.

GILLEN, Paul. "The Radical Parties and Independence: Another Scotland is Possible" in Kevin ADAMSON \& Peter LYNCH (eds.), Scottish Political Parties and the 2014 Independence Referendum, Cardiff: Welsh Academic Press, 2014.

LEES-MARSHMENT, Jennifer. Political Marketing and British Political Parties. Manchester: Manchester University Press, 2008. 
LE DUC, Laurence. "Referendums and Elections: How Do Campaigns Differ?" in David FARRELL \& Rüdiger SCHMITT-BECK (eds.), Do Political Campaigns Matter? Campaign Effect in Elections and Referendums, London: Routledge, 2002.

MAIR, Peter. Ruling the Void: The Hollowing of Western Democracy. London: Verso, 2013.

MITCHELL, James. Strategies for Self-Government. Edinburgh: Polygon, 1996.

MOODIE, Greg. Greg Moodie versus the Union. Edinburgh: National Collective, 2014.

NATIONAL COLLECTIVE. Inspired by Independence. Edinburgh: National Collective, 2014.

PANEBIANCO, Angelo. Political Parties: Organisation and Power. Cambridge: Cambridge University Press, 1988.

RIDDOCH, Lesley. Wee White Blossom: What Post-Referendum Scotland Needs to Flourish. Edinburgh: Luath Press, 2014.

SHAW, Eric. "The Scottish Labour Party and the Independence Referendum" in Kevin ADAMSON \& Peter LYNCH (eds.), Scottish Political Parties and the 2014 Independence Referendum, Cardiff: Welsh Academic Press, 2014.

\section{NOTES}

1. John CURTICE \& Rachel ORMSTON, Scottish Independence: The State of the Union: Public Opinion and the Scottish Question, British Social Attitudes, 29, 2012.

2. Laurence LE DUC, "Referendums and Elections: How Do Campaigns Differ?", pp. 159-60 in David FARRELL \& Rüdiger SCHMITT-BECK (eds.), Do Political Campaigns Matter? Campaign Effect in Elections and Referendums, London: Routledge, 2002.

3. Eric SHAW, "The Scottish Labour Party and the Independence Referendum", in Kevin ADAMSON \& Peter LYNCH (eds.), Scottish Political Parties and the 2014 Independence Referendum, Cardiff: Welsh Academic Press, 2014.

4. Manuel CASTELLS, Networks of Outrage and Hope: Social Movements in the Internet Age, London: Polity, 2012.

5. See Jack BRAND, The National Movement in Scotland, London: Routledge and Kegan Paul, 1978, and James MITCHELL, Strategies for Self-Government, Edinburgh: Polygon, 1996.

6. Kevin ADAMSON \& Peter LYNCH (eds.), Scottish Political Parties and the 2014 Independence Referendum, Cardiff: Welsh Academic Press, 2014, p. 160.

7. Or a Scottish political blog either: http://athousandflowers.net/about/.

8. See http://nationalcollective.com/yestival/.

9. Angelo PANEBIANCO, Political Parties: Organization and Power, Cambridge: Cambridge University Press, 1988.

10. Jennifer LEES-MARSHMENT, Political Marketing and British Political Parties, Manchester: Manchester University Press, 2008.

11. Peter MAIR, Ruling the Void: The Hollowing of Western Democracy, London: Verso, 2013.

12. NATIONAL COLLECTIVE, Inspired by Independence, Edinburgh: National Collective, 2014.

13. Greg MOODIE, Greg Moodie versus the Union, Edinburgh: National Collective, 2014.

14. See www.nationalcollective.com.

15. The Herald, 30 September 2014 , p. 6.

16. http://new.livestream.com/IndependenceLive.

17. Yes Scotland reported 314 local groups in June 2014. 
18. Paul GILLEN, “The Radical Parties and Independence: Another Scotland is Possible", in Kevin ADAMSON \& Peter LYNCH (eds.), Scottish Political Parties and the 2014 Independence Referendum, Cardiff: Welsh Academic Press, 2014.

19. See www.radicalindependence.org.

20. James FOLEY \& Pete RAMAND, Yes: The Radical Case for Scottish Independence, London: Pluto, 2014.

21. http://www.businessforscotland.co.uk.

22. See http://www.womenforindependence.org.

23. Kathleen CASKIE, "Women Seeking a State of Independence", Scottish Left Review, issue 84, 2014.

24. Lesley RIDDOCH, Wee White Blossom: What Post-Referendum Scotland Needs to Flourish, Edinburgh: Luath Press, 2014.

\section{ABSTRACTS}

The Scottish independence referendum of 2014 saw one of the longest political campaigns in modern UK politics. The referendum saw the formation of a hybrid Yes campaign that combined modern campaigning techniques with a large, activist grassroots that established a range of new political organisations. Not only did these organisations continue to develop after the referendum itself, but they contributed to the formation of a broad social movement in favour of independence for the first time in Scotland.

Le référendum écossais de 2014 a été précédé de l'une des plus longues campagnes politiques de l'ère moderne au Royaume-Uni. Celle-ci s'est notamment caractérisée par la formation d'une campagne pour le «oui » hybride, qui a mêlé techniques de campagne modernes et une large base activiste à l'origine de la création de nouvelles organisations politiques. Non seulement ces organisations ont continué à se développer après le référendum, mais elles ont aussi contribué à la mise en place d'un vaste mouvement social en faveur de l'indépendance pour la première fois dans l'histoire de l'Écosse.

\section{INDEX}

Mots-clés: indépendance, référendum, campagne, activisme, culture

Keywords: independence, referendum, campaigning, grassroots, culture

\section{AUTHOR}

\section{PETER LYNCH}

University of Stirling 